\title{
Kataforik. En empirisk undersøgelse af pronominelle kataforer ud fra en receptiv synsvinkel
}

Afhandlingen, som bærer originaltitlen "Kataphorik. Eine empirische Untersuchung pronominaler Kataphern aus rezeptiver Sicht", blev indleveret med henblik på erhvervelse af Ph.D.-graden den 1. september 1997. Forsvaret fandt sted den 20. februar 1998.

\section{Indledende bemærkninger}

Det overordnede formål med denne afhandling kan formuleres ganske generelt: nemlig at yde et bidrag til et kun sparsomt belyst område af den tekstlingvistiske forskning.

Afhandlingens undersøgelsesgenstand er et fænomen, som af mange opfattes som perifert og relativt uvæsentligt, nemlig den kataforiske henvisning ('Verweisung') ${ }^{1}$. Sandt er det da også, at kataforen optræder med en markant lavere frekvens end eksempelvis den beslægtede anafor, men at slutte herudfra at kataforen derfor skulle være et uinteressant randfænomen og måske blot en invers anafor uden (sær)egne egenskaber, er ud fra et overordnet videnskabeligt perspektiv decideret uhensigtsmæssigt ${ }^{2}$; jvf. her også Koeppel (1993: 5) og Krenn (1985: 3), som tematiserer samme problematik, blot med et andet udgangspunkt. Det kan lyde banalt, men det er ikke desto mindre min opfattelse, at man som lingvist løber en risiko for at overse vigtige erkendelser om spro-

1 En kataforisk relation har to konstituenter; de er begge understreget i det efterfølgende: et kataforisk udtryk/kataforikon, som i eks. i) udgøres af et personligt, i eks. ii) af et possessivisk pronomen, viser frem til et henvisningsobjekt, en postcedent, som i begge tilfælde udgøres af et proprium. Analogt hermed betegnes henvisningsobjektet i en anaforisk relation som antecedent. For en mere præcis definition henvises til afsnit 3 i nærværende tekst.

i) "Sidste nyt: Selvom han var langt fra banen, så kunne Preben Elkjær godt se, at hans hold leverede en god præstation mod AGF i søndags." (Morgenavisen Jyllandsposten, 24-11-96)

ii) "Sammenstød af interesser

I sin tid som aktiv fodboldspiller havde Preben Elkjær som varemærke, at han kunne score mål i selv de mest umulige situationer." (Morgenavisen Jyllandsposten, 22-1296).

2 Af væsentlige, nyere værker, som beskæftiger sig med kataforen, kan kort nævnes van Hoek (1997), Ke1sik (1992; 1989), Reichler-Béguelin (1988), Härmä (1987) og Maes (1987). 
gets funktion(er), hvis man på denne måde letfærdigt og affærdigende afviser at beskæftige sig med sproglige forekomster, som ved første øjekast kunne virke erkendelsesmæssigt ugivtige. Jeg mener i min afhandling at have vist, at kataforen og behandlingen af kataforen i litteraturen er et glimrende eksempel herpå, og at også iagttagelsen af sproglige 'randfænomener' kan afføde interessante resultater. Jeg vil komme nærmere ind på disses art senere.

Undersøgelsen har to underordnede formål: For det første har det været mit $\emptyset$ nske at beskrive kataforens formelle (syntaktiske og morfologiske) karakteristika, for det andet at unders $\varnothing \mathrm{ge}$ og redegøre for kataforens funktionelle karakteristika ud fra en receptiv synsvinkel.

I det følgende skal jeg kort skitsere de vigtigste resultater fra den mere formelle side af undersøgelsen.

\section{Kataforer og typologisering}

Som det fremgår af afhandlingens titel, er den empiriske undersøgelse begrænset til at omfatte pronominelle kataforer. Hemed menes kataforiske relationer, hvis foriske udtryk udgøres af en pronominel form; i det pågældende arbejde i form af enten et personligt eller et possessivisk pronomen, som også er de statistisk set hyppigst optrædende størrelser. De kataforiske udtryks morfologiske materiale danner således grundlag for en første inddeling i følgende to hovedgrupper: A) kataforer med personlige pronominer som kataforika, jvf. eksempel i), og B) kataforer med possessiviske kataforika, jvf. eksempel ii).

Denne inddeling har vist sig at være hensigtsmæssig, idet disse to gruppper udviser store forskelle i (kata)forisk perspektiv. Det personlige pronomen optræder aldrig i determinativ position, har altså ikke artikelfunktion. Det possessiviske pronomen optræder både som possessivum (substantivisk) og som possessivt determinativ. I kataforisk funktion er possessivet imidlertid yderst lavfrekvent. Derfor omfatter analysen i praksis kun substantiviske, dvs. syntaktisk selvstændige personlige pronominer og adjektiviske, dvs. syntaktisk uselvstændige possessiviske pronominer, mao.: possessive determinativer.

De kataforiske relationer kan også inddeles efter deres rækkevidde, dvs. efter afstanden mellem kataforkonstituenterne. Dette kriterium giver de følgende tre grupper:

a transperiodiske kataforer

b) transfrastiske kataforer

c) intrafrastiske kataforer ${ }^{3}$.

3 Eks. i) er en transfrastisk, eks. ii) er en intrafrastisk og eks. iii), som forefindes nedenfor, er en transperiodisk kataforisk relation. 
Også dette klassifikationskriterium har vist sig at være hensigtsmæssigt, da kataforerne i de forskellige klasser adskiller sig fra hinanden på væsentlige punkter. For analysen som sådan har det vist sig, at jo ringere kataforernes rækkevidde er, desto lettere kan man indfange syntaktiske og morfologiske regulariteter. Som følge heraf, kan man i vidt omfang kun iagttage tendenser i de transperiodiske kataforers konstruktion, da de syntaktiske muligheder her er mangfoldige, mens det for de intrafrastiske possessiviske kataforers vedkommende er muligt at foretage en endog særdeles specificeret videre inddeling efter tre prototypiske syntaktiske skabeloner. Denne inddeling vil jeg ikke komme nærmere ind på her, men i stedet henvise til afhandlingens afsnit 4.3.3.

\section{Kataforer og funktion}

Som nævnt indledningsvist er et andet kernepunkt i min afhandling det funktionelle aspekt. Efter først en summarisk redegørelse for de vigtigste grundlæggende teoretiske præmisser for arbejdet, vil jeg kort præsentere de vigtigste resultater af denne del af afhandlingen.

I den empiriske analyse har det vist sig, at kataforen ikke kan beskrives fyldestgørende ud fra de resultater, som den hidtidige forskning har afstedkommet, således som de beskrives i den indledende redegørelse for forskningsområdet 'henvisning/forik' i afhandlingens andet kapitel. Det var dog muligt at opstille et teoretisk skelet her ud fra og formulere nogle grundlæggende teoretiske antagelser for min analyse af kataforens (foriske) funktion.

\subsection{Kataforer og kontinuitet}

En grundlæggende antagelse inden for tekstlingvistikken er, at en given mængde af sproglige tegn først kan betegnes som en tekst, når disse tegn kan forbindes med hinanden på en sådan måde, at de skaber/at man kan skabe en meningsgivende sammenhæng. Med Hatakeyama/Petöfi/Sözer (1989) bruger jeg termen 'kontinuitet' som overbegreb for enhver slags sammenhæng ${ }^{4}$. Kontinuitet er ikke inhærent i en ytring/en række af ytringer, den bliver derimod først skabt af recipienten ved perceptionen af ytringen/ytringerne. Efter samme princip etableres relationen mellem de mindst to elementer $\mathrm{i}$ en forisk relation. Denne er ikke primært af strukturel/syntaktisk art, men derimod af semantisk art. Ved reception og dermed også ved resolution (af et forisk udtryk) går recipienten lineært frem, jvf. her Schwarz (1992:158). Når recipienten støder på et endoforisk udtryk, aktiverer han en søgemekanisme, som opererer ud fra de

4 Jeg behandler i mit arbejde tre slags sammenhæng, nemlig konneksitet, kohæsion og kohærens, som opererer på hver sit niveau i teksten. Begreberne dækker over et kontinuum, som starter ved en teksts formelle organisation (konneksitet), går til tekstens 'menings-semantiske' organisation (kohæsion) og ender ved dens kognitive repræsentation (kohærens). 
informationer som overfladeteksten stiller til rådighed, og som forfølger det mål at identificere det foriske udtryks henvisningsobjekt. I deres egenskab af formidlere af sådanne informationer kan endoforiske udtryk også betegnes som instruktionsbærere.

I afhandlingens kapitel 3 argumenteres for, at denne søgemekanisme ikke kun aktiveres på den materielt manifesterede og konkret foreliggende teksts niveau, men at den også (og måske primært) fungerer på det kognitive niveau, dvs. på den mentale repræsentations niveau, som recipienten bl.a. danner ud fra den konkrete tekst. Dette er naturligvis i fin overensstemmelse med den grundantagelse, at kontinuitet ikke er tekstinhærent, men derimod en egenskab, som (først er skabt af tekstproducenten og dernæst) er skabt af tekstrecipienten, og som altså ikke er fysisk præsent og ikke fremgår direkte af den sproglige overflade. Recipienten kan principielt gå frem på to måder: han kan lade den pågældende søgemekanisme operere på den manifeste teksts niveau og/eller på niveauet for tekstens mentale repræsentation.

Hvilke informationer bliver så stillet til rådighed for recipienten? Det kan kort sammenfattes som følger: Et personligt og et possessivisk pronominelt forikon bærer kun på få fundamentale informationer, såkaldte typevariabler eller med Kallmeyer et al. (1980): konneksionsanvisninger. Et forikon skal som basal funktion - bevæge recipienten til at søge efter den udfyldning af det semantiske tomrum, som et forikon repræsenterer, andetsteds. De sparsomme informationer, som forikonnet giver (det være sig eksempelvis om henvisningsobjektets genus/sexus eller numerus), kan danne grundlag for søgemekanismens operationer. Ofte er dette dog ikke tilstrækkelig solidt til, at man kan foretage en entydig bestemmelse af et henvisningsobjekt ud fra dette alene. Konstituenterne i en forisk relation behøver for det første ikke at kongruere med hinanden, og for det andet kan konneksionsanvisningerne være uentydige. Der kunne f.eks. være flere tekstkonstituenter, som bar disse kategorielle kendetegn, og som derfor måtte anses for at være lige gyldige kandidater til posten som henvisningsobjekt for det pågældende foriske udtryk.Vigtigere fikspunkter i resolutionsprocessen er de tekstinterne faktorer, de sproglige omgivelser eller koteksten, og de teksteksterne faktorer, den situationelle kontekst, kommunikationsdeltagernes viden om sprog, viden om verden etc., jvf. den model for tekstreception, som Scherner (1984:148) opstiller. Disse fikspunkter vil jeg dog ikke gå nærmere ind på her.

\subsection{Kataforer og informationsstruktur}

Men netop denne tilstedeværelse af et semantisk tomrum får konsekvenser for et andet aspekt af kataforens funktion, nemlig den informationsstrukturelle, og giver følgende to mulige funktioner: Ved at benytte sig af en kataforisk relation kan tekstproducenten introducere en tekstreferent eller et topik (dvs. et tema) 
på relativ kompakt vis. Postcedenten og dens kotekst bliver dermed fokusseret. Introduktionen betegnes som kompakt, da referenten bliver forberedt i tekstrecipientens bevidsthed. I denne proces medvirker bla. forikonnets kotekst. Koteksten giver recipienten informationer til brug for opbygningen af referenten og af dennes baggrund. Recipienten kan altså danne hypoteser om identiteten af den entitet, som henvisningsobjektet denoterer, før han når til det.

Men - og her spiller førnævnte semantiske manko ind - informationerne kan også struktureres anderledes. I afhandlingens kapitel tre anskueliggøres det, hvorledes en katafor - i stedet for at muliggøre en øjeblikkelig identikation af en tekstreferent - kan anvendes til at forberede dennes introduktion og etablering $\mathrm{i}$ et tekstunivers. Tekstreferenten forbliver på denne måde uidentificeret $i$ et stykke tid, men forsynes med egenskaber (prædikationer), således at den alligevel kan træde i karakter. Med en (pronominel) katafor kan man altså strukturere informationer på to måder: Man kan sætte fokus på referentens baggrund, dvs. på dens kotekst, ved at nedtone vigtigheden af et henvisningsobjekts identitet og dermed fokussere på andre aspekter i et tekstunivers, eller man kan - som nævnt først - slet og ret fremhæve identiteten af det denotat, som henvisningsobjektet betegner.

\subsection{Kataforer og forik}

Det primære formål med afhandlingens empiriske analyse er dog ikke at undersøge kataforens informationsstrukturerende funktion, men snarere at nå frem til en adækvat beskrivelse af et andet funktionelt aspekt, det foriske. Det viser sig nemlig, at foriske relationer er/kan være forisk mere komplekse, end man hidtil har antaget i forskningen.

I afhandlingens kapitel 4 viser jeg, at et forikon (her et pronomen) potentielt er simultant multifunktionelt. Med dette menes, at et pronomen eksempelvis kan fungere anaforisk og kataforisk på samme tid, dvs. i én tekstualisering. De forskellige foriske funktioner befinder sig dog ikke på hierarkisk ligeværdige pladser, der er mao. altid én funktion, som er dominant i forhold til den anden/de andre. Den retning, som man som tekstrecipient skal bevæge sig i for at kunne foretage en entydig identifikation af pronominets denotat, bestemmer, hvilken forisk funktion der skal betragtes som dominant. Det foriske udtryk kan både være uni- og multifunktionelt, det behøver altså ikke at udøve flere forskellige foriske funktioner i én tekstualisering.

I afhandlingen blev det ydermere vist, at også henvisningsobjektet kan udøve flere forskellige foriske funktioner i én tekstualisering. En postcedent er nemlig ikke altid kun postcedent, men kan på samme tid også fungere som antecedent. Den kan mao. være mål for flere forskellige henvisninger i samme tekstualisering. Henvisningsobjektet kan således også være såvel uni- som multifunktionelt. 
Af afhandlingens undersøgelser fremgår endvidere, at der findes konstruktioner (topologiske, syntaktiske etc.), som så at sige favoriserer kataforiske relationer, som altså kan få/får en recipient til at forvente et henvisningsobjekt i den efterfølgende i stedet for eksempelvis i den foregående kotekst.

\section{Revideret definition af kataforen}

Ved en pronominel katafor forstås det semantiske forhold mellem et semantisk set relativt tomt element, det kataforiske udtryk (et pronomen), og et semantisk set relativt fuldt element i den efterfølgende kotekst, henvisningsobjektet/postcedenten. Det kataforiske udtryk står i et interpretativt dependensforhold til postcedenten. Dette forhold er ensidigt.

Ved forudgående nævnelse af den tekstreferent, som det foriske udtryk betegner (dvs. ved tilstedeværelsen af et anaforisk henvisningsobjekt, en antecedent), gælder den kataforiske relation som primær (og den anaforiske som sekundær), hvis kun en rekurs til det efterfølgende henvisningsobjekt tillader en entydig identifikation af tekstreferenten. Princippet om identifikatorisk entydighed anses altså for at være grundlæggende.

\section{Afsluttende bemærkninger}

Som nævnt indledningsvist er det overordnede formål med denne afhandling at nå frem til ny indsigt $\mathrm{i}$ kataforen og dermed at bidrage til at udfylde et tomrum i litteraturen om forik. Jeg har i afhandlingen opstillet intersubjektivt operationaliserbare klassifikationskriterier, ved hjælp af hvilke kataforens formelle og funktionelle regelmæssigheder lader sig indfange og beskrive. Det overordnede mål må derfor betragtes som værende nået.

Det har været min hensigt at rokke ved den traditionelle opfattelse af, hvorledes et forisk pronomen rent faktisk fungerer, og slå til lyd for og levere ansatsen til en mere differentieret tilgang til udforskningen af dette område. Jeg ville - i umiddelbar forlængelse heraf - vise, at det godt kan betale sig at beskæftige sig med 'lingvistiske randfænomener', at man herigennem faktisk kan belyse aspekter af andre, beslægtede og mere anerkendte fænomener, og at et sådant arbejde måske endda kan føre til nye indsigter i disse. Dette må efter min mening også betragtes som værende gjort.

\section{Litteraturhenvisninger}

Härmä, Juhani (1987). La cataphore pronominale en français. In Neophilologica Fennica XLV. 53-69.

Hatakeyama, K., Petöfi, J. S., Sözer, E. (1989). Text, Konnexität, Kohäsion, Kohärenz. In Conte, M.-E. (ed.) (1989): Kontinuität und Diskontinuität in Texten und Sachverhaltskonfigurationen. Hamburg: Helmut Buske. 1-55. 
Kallmeyer, W., Klein, W., Meyer-Hermann, R., Netzer, K., Siebert, H.-J. (1980). Lektürekolleg zur Textlinguistik. Band 1: Einführung. Königstein: Athenäum.

Ke1sik, Marek (1989). La cataphore. Paris: Presses Universitaires de France.

Ke1sik, Marek (1992). La cataphore: Approches et problèmes. In Lingua e stile, 17. 199-214.

Koeppel, Rolf (1993). Satzbezogene Verweisformen. Eine datenbankgestützte Untersuchung zu ihrer Distribution und Funktion in mündlichen Texten, schriftlichen Texten und schriftlichen Fachtexten des Deutschen. Tübingen: Gunter Narr.

Krenn, Monika (1985). Probleme der Diskursanalyse im Englischen. Verweise mit this, that, it und Verwandtes. Tübingen: Gunter Narr.

Maes, Alfons (1987). The pragmatic value of cataphoric relations. In Nuyts, J., de Schutter, G. (eds.) (1987): Getting One's Words into Line. On Word Order and Functional Grammar. Dordrecht/Providence: Foris Publications. 131-146.

Reichler-Béguelin, Marie-José (1988). Anaphore, cataphore et mémoire discursive. In Pratiques 57. 15-43.

Scherner, Maximilian (1984). Sprache als Text. Tübingen: Niemeyer.

Schwarz, Monika (1992). Einführung in die kognitive Linguistik. Tübingen: Francke Verlag (UTB 1636).

Thomsen, René Sehested (1997). Kataphorik. Eine empirische Untersuchung pronominaler Kataphern aus rezeptiver Sicht. Århus: Handelshøjskolen i Århus (Ph.D.afhandling).

van Hoek, Karen (1997). Backwards anaphora as a constructional category. In Functions of Language 4 (1). 47-82. 
